Ks. Rafał Kamiński

Wydział Prawa Kanonicznego UKSW

ORCID 0000-0002-7822-3402

\title{
Deontologia adwokata kościelnego w procesie o stwierdzenie nieważności małżeństwa
}

Treść: Wstęp. 1. Pojęcie deontologii na gruncie nauk prawnych. 2. Wymagania prawne i etyczne stawiane adwokatom. 3. Etyczny sposób realizacji procesowych obowiązków i praw adwokata. 4. Kwestie związane z wynagrodzeniem adwokata. 5. Współpraca adwokata z trybunałem kościelnym. Zakończenie.

\section{Wstęp}

Od ponad ośmiu wieków instytucja adwokata jest obecna na gruncie prawa kościelnego. Jej pojawienie się zawdzięczamy twórcom prawa rzymskiego, które pełniło funkcję pomocniczą wobec prawa Kościoła.

Funkcja obrońcy, który w procesach kanonicznych występuje w roli rzecznika strony, a więc rzecznika jej interesu prywatnego, jest gwarantem zachowania fundamentalnego prawa do obrony. Realizacja tego uprawnienia musi jednak dokonywać się zawsze z poszanowaniem prawa oraz norm etycznych, które wyznaczają sposób działania adwokata.

Nie jest on urzędnikiem sądowym i w odróżnieniu od adwokata w sądzie cywilnym, w sądzie kościelnym nie zajmuje stanowiska prawnopublicznego. W procesach kanonicznych ta sama osoba może 
pełnić funkcję zarówno pełnomocnika, jak i adwokata, także w tej samej sprawie.

W niniejszym opracowaniu uwaga została poświęcona roli adwokata i stawianym mu wymaganiom prawnym i etycznym, w sprawach o stwierdzenie nieważności małżeństwa. W tego typu procesach kanonicznych, począwszy od promulgacji obowiązującego Kodeksu Prawa Kanonicznego rola defensora stale wzrasta. Potwierdzenie tego faktu znajduje swoje podstawy szczególnie w dwóch dokumentach papieskich, poświęconych stricte procesowi o stwierdzenie nieważności małżeństwa. Pierwszym z nich jest wydana przez Jana Pawła II instrukcja procesowa Dignitas connubii ${ }^{1}$, drugim motu proprio papieża Franciszka Mitis Iudex Dominus Iesus, którym przed ponad pięcioma laty, znacznie zreformował normy proceduralne małżeńskiego procesu de nullitate 2 .

Po reformie papieża Franciszka nie ma co prawda w prawie nowych postanowień dotyczących adwokatów, jednak w świetle tego dokumentu, jego posługa w procesie kanonicznym o stwierdzenie nieważności małżeństwa, nabiera jeszcze większego znaczenia. Franciszek zwraca uwagę nie tylko na możliwość jego udziału w procesie, ale formułuje zachętę do korzystania przez strony z jego aktywnej posługi. Ma ona szczególne znaczenie w przypadku, gdy pierwszoinstancyjne wyroki pro nullitate, mogą być prawnie obowiązujące, a także w nowym trybie processus brevior, toczącym się przed biskupem.

Wobec upowszechnienia się obecności adwokatów w procesach o stwierdzenie nieważności małżeństwa i zróżnicowanym poziomie świadczonej przez nich pomocy prawnej, zasadnym wydaje się

1 Pontificium Consilium de Legum Textibus, Instructio Dignitas Connubii servanda a tribunalibus dioecesanis et interdioecesanis in pertractandis causis nullitatis matrimonii, Roma 2005, art. 101-113. (Dalej: DC).

2 Franciscus, Litterae Apostolicae Motu Proprio datae „,Mitis Iudex Dominus Iesus" quibus canones Codicis Iuris Canonici de causis ad matrimonii nullitatem declarandam reformatur, http://www.vatican.va/content/francesco/pl/motu_proprio/ documents/papa-francesco-motu-proprio_20150815_mitis-iudex-dominus-iesus. html [dostęp 3.01.2021], art. 3, kan. $1677 \$ 1$; Zasady proceduralne, art. 4 i art. $18 \$ 1$. (Dalej: MIDI). 
zwrócenie uwagi nie tylko na normatywny, ale także i na etyczny wymiar ich posługi.

\section{Pojęcie deontologii na gruncie nauk prawnych}

Dziedzinę zajmującą się nauką o moralności, którą od czasów Cycerona uznawano za naukę o obowiązkach, stworzył w XIX wieku Jeremy Bentham, który widział w niej zbiór reguł zachowania, obowiązujących w określonej grupie zawodowej ${ }^{3}$.

Wywodząca swą nazwę od dwóch słów greckich deon (obowiązek) i logos (słowo, nauka) dyscyplina nazwana deontologią, zajmuje się zatem pojęciem obowiązku i związanymi z nim sposobami zachowania. Służy to zagwarantowaniu odpowiedniej wartości profesjonalnie wykonywanej działalności ${ }^{4}$, stwarzając podstawy etyczne spełnianych czynności zawodowych oraz formułując powinności i imperatyw moralny, które nimi kierująa . W znaczeniu potocznym będzie to więc postępowanie zgodnie z zasadami danej dyscypliny zawodowej.

Współcześnie deontologia stanowi jeden z działów etyki, jako filozoficznej nauki o moralności, który zajmuje się znaczeniem powinności i imperatywu moralnego ${ }^{6}$.

Jak zauważa Tomasz Gałkowski, chociaż pojęcia: prawo i obowiązek, na gruncie nauk prawnych stanowią podstawę prowadzonego w nich dyskursu, pojęcie deontologii nie doczekało się w nich znaczącego miejsca, ograniczając się jedynie do nielicznych przykładów posługiwania się tą terminologią poprzez odwołanie się do terminów klasycznych filozofii ${ }^{7}$.

Ujęcia, w formie swoistego katalogu, powinności etycznych poszczególnych zawodów prawniczych znajdują się przede wszystkim

3 Por. J. Bentham, Deontology, Science of Morality, London 1834.

4 Por. T. GaŁkowski, Prawo-Obowiązek. Pierwszeństwo i współzależność w porządkach prawnych: kanonicznym i społecznośco świeckiej, Warszawa 2007, s. 26.

5 Por. D. Gutmann, L'obligation déontologique entre l'obligation morale et l'obligation juridique, APhD 44 (2000), s. 117-118.

6 Por. T. GaŁkowski, Prawo-Obowiązek..., dz. cyt., s. 26.

7 Por. TAmże, s. 27. 
w kodeksach etycznych, choć także w odpowiednich ustawach nie brakuje zapisów o charakterze etycznym ${ }^{8}$. Naruszenie obowiązków etycznych ciążących na prawnikach pociąga za sobą niezależną od ewentualnej odpowiedzialności karnej, odpowiedzialność dyscyplinarną9

$\mathrm{Na}$ gruncie prawa kanonicznego są również uregulowania ustawowe, przewidujące sankcje za naruszenia etyczne, wciąż jednak w rzeczywistości polskiej brakuje uregulowań, które na wzór norm cywilnych powodowałyby swoistą weryfikację środowiska adwokatów kościelnych. Stosunkowo niedawno pojawił się także „Kodeks Etyki Adwokata Kościelnego"10. Należy on do grupy dokumentów, będących deklaracją samego środowiska, które powinno stosować się do ich postanowień.

\section{Wymagania prawne i etyczne stawiane adwokatom}

Źródłem powstania obowiązku, w odniesieniu do człowieka, może być istniejące prawo albo też normy życia społecznego, czy też normy moralne. Obowiązki prawne są również poddawane ocenie moralnej ${ }^{11}$. Zależność między prawem a moralnością jest dostrzegalna także w sformułowanych przez normy prawa kanonicznego wymaganiach stawianych adwokatom kościelnym. Kan. 1483 KPK, stanowi: „Pełnomocnik i adwokat winni być pełnoletni i nienaruszonej sławy.

\footnotetext{
8 Przykładem takiej regulacji, dotyczącej adwokatów cywilnych, jest Ustawa z 26 maja 1982 r. Prawo o adwokaturze (Dz.U. z 2002 r. nr 132 poz. 1058 z późn. zm.).

9 H. Izdebski, P. Skuczyński (red.), Etyka zawodów prawniczych. Etyka prawnicza, Warszawa 2006, s. 8.

10 Krajowa Izba Adwokatów Kościelnych, Kodeks Etyki Adwokata Kościelnego, https://sites.google.com/site/korpusadwokatowkoscielnych/home/statut-kiak/ kodeks-etyki-adwokata-koscielnego [dostęp 3.01.2021]. (Dalej: KEAK). Kodeks został uchwalony na I Walnym Zgromadzeniu Krajowej Izby Adwokatów Kościelnych, które miało miejsce 10 czerwca 2019 r. w Gródku n. Dunajcem, w czasie IX Ogólnopolskiego Forum Sądowego. Jego korekt dokonano 21 sierpnia 2019 r. przez Zarząd Krajowej Izby Adwokatów Kościelnych, na podstawie upoważnienia Walnego Zgromadzenia.

11 Por. T. GaŁkowski, Prawo-Obowiązek..., dz. cyt., s. 58.
} 
Adwokat ma być ponadto katolikiem, chyba że biskup diecezjalny zezwoli inaczej, doktorem prawa kanonicznego lub skądinąd prawdziwie biegłym i zatwierdzonym przez tegoż biskupa”.

Pośród pięciu warunków stawianych przez ustawodawcę, które musi spełnić kandydat na stanowisko adwokata kościelnego, dwa dotyczą wprost kierowania się określoną moralnością, związaną z chrześcijańskim światem wartości. Są to nienaruszona sława oraz wyznawanie wiary katolickiej. Pozostałe wymagania dotyczą wieku, wykształcenia i wiedzy oraz zatwierdzenia przez kompetentną władzę kościelną. Poszczególne warunki, zostaną poddane refleksji według kolejności ich występowania w treści kan. 1483 KPK.

Pierwszym z nich jest wymóg pełnoletności. Ponieważ wymóg ten jest wspólny dla pełnomocnika i adwokata, w cytowanej normie odnosi się on przede wszystkim do pierwszego z nich. Pełnomocnik, chcąc podejmować w imieniu reprezentowanej osoby wszystkie czynności prawne, musi posiadać do tego pełną zdolność. Jednym z jej warunków jest odpowiedni wiek, za który przepis uznaje pełnoletność. W obowiązującym Kodeksie Prawa Kanonicznego jest nią ukończone osiemnaście lat (por. kan. $97 \mathrm{KPK})^{12}$.

Jest rzeczą logiczną, że adwokat, który zgodnie z wymogiem dotyczącym odpowiedniego wykształcenia ukończył studia i posiada stopień naukowy, zawsze będzie osobą pełnoletnią.

Warto nadmienić, że zgodnie z kan. $99 \mathrm{KPK}$ osoby nie posiadające używania rozumu (także w fazie remisji choroby), przyrównane są dzieciom, za które w prawie kanonicznym uważa się osoby małoletnie przed ukończeniem siódmego roku życia (por. kan. $97 \$ 2 \mathrm{KPK}$ ).

Brak ten wymaga udowodnienia, a osoby takie są uznane za niezdolne do czynności prawnych, nie mają zdolności procesowej, są niepoczytalne i nie podlegają ustawom kościelnym ${ }^{13}$. Gdyby całkowity brak używania rozumu zweryfikował się w czasie pełnienia funkcji

\footnotetext{
12 Według poprzedniego Kodeksu z 1917 roku, granicą pełnoletności było ukończenie 21. roku życia. Por. can. $88 \$ 1$ CIC 1917.

13 Por. R. Sobański, Statuty i przepisy porzadkowe, w: J. KRUKOwski, R. Sobański, Komentarz do Kodeksu Prawa Kanonicznego, t. 1, Poznań 2003, s. 168-169.
} 
adwokata, osoba taka powinna zostać skreślona $\mathrm{z}$ listy adwokatów ${ }^{14}$. Dwa kolejne wymogi, a więc nienaruszona sława i bycie katolikiem, wiążą się wprost z kierowaniem się moralnością chrześcijańską.

Wymieniony w treści przepisu wymóg „nienaruszonej sławy” (bona fama) jest czymś więcej, niż nieznajdowanie się w karze infamii, jak widział to prawodawca w poprzedniej kodyfikacji ${ }^{15}$.

Jak zauważa Joaquín Llobel, bona fama wiąże się ze stylem życia i koherencją w postępowaniu, które respektuje przynajmniej normy prawa naturalnego ${ }^{16}$. Nie należy do łatwości dokonanie oceny czyjegoś postępowania i określenie, czy cieszy się on nienaruszoną sławą, czyli innymi słowy, odnosząc to do osoby adwokata kościelnego, określić, co znaczy być dobrze postrzeganym we wspólnocie Kościoła partykularnego, w której dany adwokat sprawuje swoją funkcję.

Pewnej pomocy dostarcza w tym zakresie motu proprio Jana Pawła II Iustii iudicis, formułujące wymogi dla adwokatów Kurii Rzymskiej, wśród których znajdują się: wyjątkowa (praecellenti), doskonała integralność życia chrześcijańskiego; czynne uczestnictwo w życiu własnej wspólnoty kościelnej, według własnego powołania; wyznawanie wiary katolickiej; niepozostawanie w nieuporządkowanych związkach małżeńskich; niesprzeciwianie się nakazom doktrynalnym i pastoralnym legalnej władzy kościelnej; niepopieranie ustaw świeckich sprzeciwiających się prawu naturalnemu lub prawom Kościoła; nienależenie do organizacji występujących przeciwko Kościołowi; brak współpracy z organizacjami, które kierują

14 Por. J. Llobel, Le parti, la capacità processuale e i patroni nell'ordinamento canonico, Ius Ecclesiae 12 (2000), s. 90.

15 W Kodeksie z 1917 utrata dobrego imienia mogła nastąpić na skutek popełnienia przestępstwa, co stwierdzał wyrok sądowy lub też w związku z utratą szacunku społecznego wskutek złych obyczajów. Por. CIC 1917: can. 2320, can. 2343, can. 2328, can. 2356, can. 2357, can. 2314, can, 2359, can. 2315, can. 2384, can. 2375, can. 2353, can. 1743 , can. 2350 , can. 2357, can. 2303, can. 2294, can. 2263. Osoby takie mogły zostać ipso facto usunięte z urzędu. Por. CIC 1917, can. $1640 \$ 2$.

16 Por. J. Llobel, Avvocati e procuratori nel processo canonico di nullità matrimoniale, Apolinaris 61 (1988), s. 784-785. 
się zasadami przeciwnymi wierze i moralności chrześcijańskiej ${ }^{17}$. Niektóre z powyższych kryteriów odpowiednio i analogicznie zastosowane, mogą służyć pomocą w określeniu posiadania nienaruszonej sławy lub jej braku, w przypadku każdego z adwokatów kościelnych. Przydatna w ocenie może być także „Odpowiedź Sygnatury Apostolskiej” z 12 VII 1993 roku, która odnosi się do konkretnego sądu diecezjalnego. W odpowiedzi na zadane pytanie rzymskiemu trybunałowi administracyjnemu, informuje on, że nie można dopuszczać do funkcji adwokata osób, które żyją w związkach nieregularnych (wolny związek, konkubinat, związek obowiązujący tylko w prawie świeckim). Ta sama przyczyna upoważnia do skreślenia z listy adwokatów. Ryszard Sztychmiler uważa, że reskrypt ten, choć jest to akt szczegółowy, można stosować do rozwiązywania podobnych szczegółowych przypadków, także w innych sądach ${ }^{18}$.

Choć prawodawca domaga się posiadania przez adwokatów nienaruszonej sławy, nie przewiduje procedury jej sprawdzania. Środkiem pomocnym w tym zakresie może być opinia o wierze i moralności, uzyskana od własnego proboszcza lub profesora, który pełnił na przykład funkcję promotora pracy naukowej zainteresowanego adwokata. Powinien on cieszyć się dobrą sławą, nie tylko w czasie zatwierdzania na urząd, ale i przez cały czas wykonywania posługi.

Za naruszenia dobrej sławy mogą zostać uznane na przykład opuszczenie życia sakramentalnego czy też nieregularna sytuacja małżeńska.

Carmelo De Diego Lora stoi na stanowisku, że jest nim także występowanie w sprawie rozwodowej swojego klienta (poza przypadkami zgodnymi z prawem, jak wcześniejszy wyrok pro nullitate, dyspensa super rato, separacja kanoniczna). Jego zdaniem, sytuacja

\footnotetext{
17 Ioannes Paulus II, Litterae Apostolicae Motu Proprio datae Iusti iudicis, 28 VI 1988, AAS 80 (1988), s. 1259, (art. 3, 6).

18 Por. R. SzTychmiler, Adwokat w procesie o nieważność małżeństwa, w: T. RozKRUT (red.), Proces małżeński w świetle „Dignitas connubii”-pierwsze doświadczenia. Materiały z ogólnopolskiego spotkania pracowników sądownictwa kościelnego w Gródku nad Dunajcem w dniach 11-12 czerwca 2007 roku, Tarnów 2008, s. 108.
} 
taka jest traktowana jako występowanie przeciw nierozerwalności małżeństwa oraz naruszenie kompetencji sądownictwa kościelnego w tego rodzaju sprawach ${ }^{19}$.

W praktyce zdarza się niestety nagminnie, że adwokat posiadający uprawnienia do występowania w procesach kanonicznych, prowadzi praktykę, także jako adwokat cywilny. Nierzadko stronie zgłaszającej się ze sprawą rozwodową, proponuje „kompleksową usługe”, która ma polegać na próbie uregulowania jego sytuacji, poprzez wniesienie także skargi o nieważność małżeństwa kanonicznego do sądu kościelnego $^{20}$.

Kolejne z kryteriów ustanowionych przez prawodawcę w kan. $1483 \mathrm{KPK}$, również ściśle związane jest z kierowaniem się określoną moralnością.

Wymóg bycia katolikiem w przypadku adwokata suponuje bowiem element religijności i moralności w jego postawie. Nie jest to warunek czysto administracyjny, ale związany z naturą instytucjonalnej funkcji, ochrony uprawnień wiernych i chrześcijańskiej koncepcji nierozerwalności małżeństwa. Adwokat winien zatem znać, rozumieć i akceptować naukę Kościoła katolickiego, szczególnie tę związaną $\mathrm{z}$ nierozerwalnością małżeństwa ${ }^{21}$. W przypadku adwokatów cywilnych istnieje obawa, że ich postępowanie może być naznaczone mentalnością rozwodową, która ukierunkowana jest na wygranie sprawy dla swojego klienta, nie zaś na współpracę w celu znalezienia obiektywnej prawdy o jego małżeństwie. Bycie katolikiem nie jest wymogiem bezwzględnym. Biskup miejsca, w którym znajduje się trybunał, gdzie występuje dany adwokat, może skorzystać z klauzuli zwalniającej go od tego wymogu i zatwierdzenie ad causam, do poszczególnego procesu. Możliwość ta przewidziana jest dla

\footnotetext{
19 Por. C. De Diego Lora, Estudios de Derecho processual canónico (Posteriores al Código de 1983), t. 4: Función pastoral y justiciar, Pamplona 1990, s. 175.

20 Por. T. BiaŁobrzeski, Współpraca adwokatów z sąami kościelnymi, Ius Matrimoniale 29 (2018) nr 3, s. 89.

21 Por. A.G. MizıŃski, Status prawny adwokata w Kościele łacińskim, Lublin 2011, s. 252.
} 
przypadków, w których istnieje niemożność występowania katolika w roli adwokata, $\mathrm{z}$ powodu braku listy stałych defensorów przy danym trybunale, przy jednoczesnej konieczności występowania adwokata w sprawie, albo też gdy wyboru adwokata dokonuje strona niekatolicka. W takiej sytuacji wybrany, mimo że nie jest katolikiem, powinien gwarantować poszanowanie kanonicznego porządku prawnego ${ }^{22}$.

Dwa kolejne wymogi odnoszą się do wykształcenia lub biegłości w zakresie prawa oraz aprobaty kościelnej.

Chociaż doktorat z prawa kanonicznego nie jest wymogiem absolutnym, powinien dawać pierwszeństwo starającym się o uzyskanie aprobaty i możliwości wykonywania posługi, podobnie jak praktyka w zawodzie, wiedza, zdolności i wysoki poziom moralny.

Na równi ze stopniem naukowym, prawodawca stawia „prawdziwą biegłość” w prawie kanonicznym. Biegłość takową zdobywa się poprzez ciągłe podnoszenie kwalifikacji i zdobywanie wiedzy. Niestety należy ubolewać, że nie jest to obowiązek ustawowy, choć konieczny w praktyce zawodowej. Adwokaci cywilni są zobowiązani nie tylko do ukończenia studiów i aplikacji, ale też i do stałego podnoszenia swoich kwalifikacji ${ }^{23}$. Na gruncie prawa kanonicznego, mimo organizowania

22 Por. A.G. Miziński, Instytucja obrońcy stałego w Kodeksie Prawa Kanonicznego z 1983 roku, Roczniki Nauk Prawnych 14 (2004) nr 2, s. 180.

23 Prawo polskie, które wymaga od adwokatów nieustannego doskonalenia zawodowego reguluje to w $\$ 4$-5 Uchwały nr 49/2015 Naczelnej Rady Adwokackiej z 13 listopada 2015 r., w sprawie zmiany uchwały nr 57/2011 z 19 listopada 2011 r. „O doskonaleniu zawodowym adwokatów”, ze zmianami wprowadzonymi uchwałą nr 70/2012 z 17 marca 2012 r. Tekst jednolity ogłoszony obwieszczeniem Prezydium NRA z 29 października 2013 r. Wśród form doskonalenia prawodawca wyróżnia: uczestnictwo w szkoleniach zawodowych organizowanych przez samorząd zawodowy adwokatury; udział w szkoleniach, seminariach, konferencjach lub wykładach organizowanych przez inne instytucje, niż samorząd zawodowy adwokatury; samokształcenie, które wyraża się bądź w przygotowaniu i publikacji opracowania o charakterze naukowym oraz publicystyczno-prawnym, bądź w przygotowaniu i przeprowadzeniu wystąpienia w ramach form szkolenia; prowadzenie zajęć szkoleniowych dla aplikantów adwokackich w ramach szkolenia organizowanego przez samorząd zawodowy adwokatury oraz zajęć w zakresie edukacji prawnej w szkołach ponadgimnazjalnych $w$ ramach akcji społecznych prowadzonych przez samorząd 
poprzez poszczególne ośrodki naukowe kursów dokształcających, czy też studiów podyplomowych w zakresie administracji i sądownictwa kościelnego, ich ukończenie oraz odpowiedni staż, na wzór świeckiej aplikacji, nie jest wymagany, co z całą pewnością ma wpływ na jakość pełnionej posługi.

Konieczność dokształcania się i podnoszenia swoich kwalifikacji jest więc kwestią etycznego podejścia do swoich obowiązków, a więc pracowitości, zarówno w kształceniu się jak i w aktualizowaniu wiadomości prawniczych ${ }^{24}$.

Jakość wykonywanej przez adwokatów kościelnych pracy wymaga ich doskonalenia zawodowego, ponieważ prawo kanoniczne małżeńskie, zarówno materialne, jak i procesowe podlega procesowi nowelizacji. Corocznie są publikowane wyroki Trybunału Roty Rzymskiej, które tworzą nowe linie orzecznictwa kościelnego. Chociaż językiem oryginalnym rotalnych wyroków jest łacina, której znajomość może stanowić barierę, to jednak wiele $\mathrm{z}$ orzeczeń jest komentowanych

zawodowy adwokatury. Przedmiotem doskonalenia zawodowego są natomiast: poszczególne dziedziny prawa, w tym praktyka jego stosowania; teoria państwa i prawa; zagadnienia prawno-porównawcze; zagadnienia etyki adwokackiej; ogólne umiejętności prawnicze, takie jak zagadnienia metod wykładni prawa, zagadnienia wystąpień publicznych i retoryki, nauka obcego języka prawniczego; zagadnienia specjalistyczne związane z wykonywaniem zawodu adwokata lub których znajomość może być przydatna przy wykonywaniu zawodu adwokata, np. z zakresu kryminalistyki, rzeczoznawstwa; zagadnienia adaptacji do wymagań klientów i rynku usług prawnych, przez co należy rozumieć m.in. zagadnienia związane z organizacją pracy adwokata, organizacją kancelarii prawnej, informatyzacją i wykorzystaniem nowych technologii, opodatkowaniem usług świadczonych przez adwokatów, marketingiem usług prawniczych, kontaktów z klientami. Por. Obwieszczenie Prezydium Naczelnej Rady Adwokackiej z 15 grudnia 2015 r. w sprawie ogłoszenia jednolitego tekstu „O doskonaleniu zawodowym adwokatów”, http://www.nra.pl/admin/wgrane_dokumenty/Tekst_jednolity_O_doskonaleniu_zawodowym_adwokatow.pdf [dostęp 3.01.2021]. Analogiczne wymagania, w zakresie prawa kanonicznego, powinno się również postawić adwokatom kościelnym.

24 Por. A.G. Miziński, Status prawny adwokata $w$ Kościele łacińskim, dz. cyt., s. 256. 
w językach nowożytnych, w tym w języku polskim ${ }^{25}$. Zapoznawanie się z tymi publikacjami powinno być konieczną osobistą pracą adwokatów w aktualizowaniu swojej wiedzy.

Kodeks Etyczny polskich adwokatów kościelnych, zwraca uwagę nie tylko na konieczność podnoszenia kompetencji zawodowych. Obowiązkiem adwokata, zapisanym w kodeksie jest także jego „(..) osobisty rozwój duchowy tak, by charakteryzował się silną i dojrzałą osobowością ukształtowaną w duchu katolickim oraz rzetelnością i sumiennością, tak by świadczone przez niego usługi i porady były na najwyższym poziomie"26.

Ostatni z ustawowych wymogów, stawianych kościelnym obrońcom dotyczy zatwierdzenia przez biskupa diecezjalnego, który powinien w tej materii wydać dekret nominacyjny (por. kan. 1483 KPK; art. 105 DC). Jest to wymaganie większe niż w przypadku ustanowienia pełnomocnika, który podobnego zatwierdzenia nie potrzebuje.

Jego uzyskanie, w przypadku adwokata, uzależnione jest od spełnienia przez niego wyżej opisanych warunków. W celu ich weryfikacji, szczególnie w zakresie posiadanej wiedzy i bonae famae, prawo partykularne może konkretyzować wymogi kodeksowe, dostosowując je do określonych warunków miejsca i $\operatorname{czasu}^{27}$.

Przewidziane są dwie formy zatwierdzenia obrońcy. Pierwszą z nich jest wpisanie na listę stałych adwokatów przy danym trybunale, które jest równoznaczne $\mathrm{z}$ zatwierdzeniem $\mathrm{w}$ formie ogólnej do wszystkich spraw przed nim się toczących. Taki adwokat zostaje mianowany na urząd kościelny.

Drugą formą aprobaty jest zatwierdzenie ad causam, a zatem do konkretnej, pojedynczej sprawy. Tak zatwierdzony adwokat zostaje włączony do procesu przez uprzednie zlecenie udzielone przez stronę lub też ex officio dekretem sędziego. Aprobata stała udzielana jest na

\footnotetext{
25 Na gruncie polskim szczególnie cenne są komentarze profesorów Wydziału Prawa UKSW: Gintera Dzierżona i Wojciecha Góralskiego.

26 KEAK, art. 2.

27 Por. A.G. Miziński, Status prawny adwokata w Kościele łacińskim, dz. cyt., s. 259 .
} 
czas określony lub bezterminowo i jest skuteczna tylko w obrębie danej diecezji.

Wyjątkiem od reguły jest zwolnienie od wymogu zatwierdzenia w przypadku adwokata z dyplomem Roty Rzymskiej (por. art. 105 $\$ 2$ DC). Gdyby takiemu adwokatowi biskup diecezjalny odmówił występowania w sprawie, do której uzyskał zlecenie strony, może on skorzystać z przysługującego mu od decyzji biskupa rekursu do Sygnatury Apostolskiej ${ }^{28}$.

W podsumowaniu tej części refleksji należy zauważyć, że wspomniany wyżej polski „Kodeks Etyki Adwokata Kościelnego”, jako jedną z zasad podstawowych uznaje, że etyka obrońcy wynika z norm etyki katolickiej przystosowanych do zawodu adwokata kościelnego. Ma on pamiętać, że salus animarum suprema lex est, a czynności zawodowe powinien wykonywać, traktując je jako służbę Bogu i człowiekowi, według najlepszej woli i wiedzy, z należytą uczciwością, sumiennością i gorliwością ${ }^{29}$.

\section{Etyczny sposób realizacji procesowych obowiązków i praw adwokata}

Posługa adwokata w procesie o stwierdzenie nieważności małżeństwa powinna być prowadzona zgodnie z obowiązującym prawem, a jednocześnie twórczo i zdecydowanie, aby pomóc w osiągnięciu zamierzonego dobrego skutku. Odbywa się to przede wszystkim poprzez wnikliwość w badaniu faktów i interpretowaniu norm prawnych ${ }^{30}$.

Skuteczność ta musi jednak respektować również normy etyczne, tak by działanie było prowadzone uczciwie, z poszanowaniem obiektywnej prawdy. Nie chodzi bowiem o próbę uzyskania wyroku pro

\footnotetext{
28 Por. TAMżE, s. 258

29 Por. KEAK, rozdz. I, pkt 1-2.

30 Por. R. SzTychmiler, Dynamiczna posługa adwokata $w$ zreformowanym procesie małżeńskim, w: T. Rozkrut (red.), Reforma procesowa papieża Franciszka-pierwsze doświadczenia. Materiały z ogólnopolskiego spotkania pracowników sądownictwa kościelnego w Gródku nad Dunajcem w dniach 12-13 czerwca 2017 roku. VIII Ogólnopolskie Forum Sądowe, Tarnów 2018, s. 94.
} 
nullitate za wszelką cenę. Sprawa o stwierdzenie nieważności małżeństwa, nie jest „rozwodową sprawą do wygrania” i nie chodzi w niej o osiągnięcie jak najkorzystniejszego rozstrzygnięcia „kosztem” drugiej strony. Zwracał na to uwagę papież Benedykt XVI w swoim pierwszym przemówieniu rotalnym w 2006 r., podkreślając, że proces o nieważność małżeństwa nie jest skierowany przeciwko drugiej stronie. Nie „sądzi się w nim stron”. Przedmiotem tego procesu jest deklaracja prawdy na temat ewentualnej nieważności konkretnego węzła ${ }^{31}$.

Do poszukiwania wspomnianej wyżej prawdy zobowiązany jest nie tylko sędzia, ale każdy uczestnik procesu, w tym także adwokat reprezentujący stronę procesową. Zadaniem wszystkich osób zaangażowanych w kanoniczny proces o nieważność małżeństwa jest więc prowadzenie działań w kierunku rei veritate ${ }^{32}$. Uczestnicy procesu działają w służbie prawdy i dobra dusz, odgrywając wzajemnie skoordynowane role, których nie wolno mieszać ani zamazywać ${ }^{33}$.

Dokonując analizy procesowych obowiązków i uprawnień adwokata, pod kątem korzystania z nich i pełnienia ich w sposób etyczny, można podzielić je na stałe obowiązki i uprawnienia niezależne od przebiegu procesu oraz na obowiązki i uprawnienia właściwe dla poszczególnych etapów przewodu sądowego ${ }^{34}$.

Wśród pierwszej grupy obowiązków należy wyróżnić kolejno: dostępność dla reprezentowanej strony, która dokonuje się poprzez udostępnienie adresu do kontaktu oraz informowanie klienta o etapach

\footnotetext{
31 Benedictus XVI, Ad Tribunal Rotae Romanae, AAS 98 (2006) cz. 2, s. 135 [135-138]. W podobnym duchu wypowiadał się wcześniej także papież Jan Paweł II. Por. Ioannes Paulus II, Allocutio ad Tribunalis Sacrae Romanae Rotae Decanum, Praelatos Auditores, Officiales et Advocatos, novo Litibus iudicandis ineunte anno: de veritate iustitiae matre, 4.02.1980, AAS 72 (1980) s. 172-178; IoANNEs PAULus II, Allocutio ad Sacrae Romanae Rotae Tribunalis Praelatos Auditores, Officiales et Advocatos coram admissos, 28.01.1982, AAS 74 (1982), s. 449-454.

32 Por. S. Pikus, Niezawisłość sędziego kościelnego, Lublin-Sandomierz 2009, s. 181.

33 Por. R. SobAŃski, Udział adwokata $w$ procesie o nieważność małżeństwa, Ius Matrimoniale 2 (1997), s. 131-132.

34 Por. R. Sztychmiler, Dynamiczna posługa adwokata..., dz. cyt., s. 95-102.
} 
i stanie procesu; działanie w interesie strony (por. art. 104 DC), ale nie za wszelką cenę, co oznacza respekt dla przepisów procesowych; prowadzenie sprawy uczciwie (por. kan. 1489 KPK), które zakłada podejmowanie godziwych działań; troska o sprawny przebieg procesu, terminowość etapów, naleganie na przyspieszenie w razie potrzeby; zależność porządkowa i niezależność merytoryczna od sędziego. Obu przecież zależy na wyjaśnieniu sprawy, stąd sędzia będzie nalegał na zakończenie sprawy, a adwokat na wykorzystanie wszystkich zgodnych z prawem możliwości dla uzasadnienia żądania strony ${ }^{35}$; świadczenie stronie pomocy za godziwą, ale nie wygórowaną zapłatę (kan. $1488 \$ 1$ KPK). Temu zagadnieniu w niniejszej refleksji poświęcono poniżej oddzielne miejsce.

Kolejne obowiązki stałe adwokata to dostępność dla trybunału, któremu winien być znany adres i telefon obrońcy; utrzymywanie z trybunałem kontaktu (nie musi mieszkać na terenie jurysdykcji trybunału, tak jak pełnomocnik); okazywanie szacunku trybunałowi (por. kan. $1470 \$ 2 \mathrm{KPK}$ ); zachowanie konwencji, co zakłada formułowanie sprzeciwu nie tylko w sposób zgodny z prawem (np. prawnie uzasadniona nielegalność lub niezasadność decyzji), ale i w sposób godny i w zgodzie z kanonami kultury osobistej ${ }^{36}$.

Wśród stałych uprawnień defensora wyróżnia się prawo do powiadamiania przez trybunał o czynnościach, w których może brać udział; uzgadnianie przez trybunał terminów czynności z jego udziałem; prawo wglądu do akt przez cały proces, co zakłada po stronie defensora zobowiązanie do dyskrecji i tajemnicy (szczególnie przy dokumentach drażliwych, których nie udostępnia się stronom); prawo otrzymywania kopii dokumentów z akt sądowych - potrzebnych odpisów w czasie publikacji akt i po niej (kan. $1598 \$ 1 \mathrm{KPK}$ ). W przypadku otrzymania przez adwokata (podczas publikacji) odpisu akt, ciąży na nim poważny obowiązek (gravis obligatio) nieprzekazywania go, w całości lub w części, innym, łącznie ze stronami (art. $235 \$ 2$ DC).

\footnotetext{
35 Por. TAMŻE, s. 95.

36 TAMŻE, s. 96-97.
} 
W związku z powyżej opisanym uprawnieniem, które dotyczy dostępu do akt sądowych, a także otrzymywaniem ich ewentualnych odpisów powstaje kilka pytań: W jakim miejscu i formie mają być one przechowywane przez adwokata? Co dzieje się z dokumentami po zakończeniu procesu? Przez jaki czas powinny być przechowywane przez adwokata? Jak powinna wyglądać procedura niszczenia tych dokumentów?

Tomasz Białobrzeski, który podejmuje to zagadnienie, zauważa, że w tych kwestiach ustawodawca kościelny zachowuje milczenie. Proponowanym przez tego Autora rozwiązaniem jest uregulowanie kwestii przez poszczególne Konferencje Biskupów lub zawarcie ich w regulaminach poszczególnych sądów biskupich. Inną formą rozwiązania tych problemów, zdaniem Białobrzeskiego, jest przechowywanie akt zebranych przez adwokata $\mathrm{w}$ danej sprawie razem $\mathrm{z}$ aktami sądowymi w archiwum sądu biskupiego lub kurii diecezjalnej ${ }^{37}$.

Próbując rozwiązać zarysowane problemy, można by skorzystać z rozwiązań prawa państwowego. „Regulamin wykonywania zawodu adwokata w kancelarii indywidualnej lub spółkach” z 7 lipca 2015 roku, zawiera w tym zakresie szczegółowe regulacje $\mathrm{e}^{38}$.

37 Por. T. BiaŁobrzeski, Współpraca adwokatów z sądami kościelnymi, dz. cyt., s. 94-95.

38 Por. Obwieszczenie Prezydium Naczelnej Rady Adwokackiej, z 7 lipca 2015 r., $w$ sprawie ogłoszenia jednolitego tekstu „Regulaminu wykonywania zawodu adwokata w kancelarii indywidualnej lub spółkach”, http://www.nra.pl/dokumenty. php?slowa $=$ Regulaminu+wykonywania + zawodu+adwokata\&kategoria $=0 \&$ datao $\mathrm{d}=2015 \&$ datado=3000\&organ $=$ selected \&typ $=$ selected \&sort $=1 \&$ limit $=50$ [dostęp 5.01.2021]. W $\$ 5$ i $\$ 7$ wskazanego dokumentu postanowiono: „2) Adwokat powinien przechowywać dokumenty związane z prowadzeniem sprawy przez okres jednego roku od wykonania zlecenia, chyba że w umowie o świadczenie usług adwokackich strony postanowiły inaczej. (...); 7) Po wykonaniu zlecenia, należy wezwać klienta do odbioru powierzonych adwokatowi dokumentów, jeżeli wynika to z umowy bądź innych ustaleń z klientem; 8) Na żądanie klienta, adwokat bez zbędnej zwłoki po zakończeniu prowadzenia sprawy zwraca dokumenty związane ze sprawą, co nie stoi na przeszkodzie zachowaniu kopii tych dokumentów przez adwokata (...); 9) Jeżeli dokumentów archiwalnych lub zabytkowych nie można zwrócić uprawnionej osobie, terminy przechowywania określają przepisy obowiązującego prawa” 
Jak konstatuje T. Białobrzeski „mając na uwadze, iż wielu adwokatów łączy funkcję adwokata cywilnego i kościelnego, znany jest im sposób postępowania z dokumentami procesowymi i trzeba wymagać, by również do tych kanonicznych stosowali zasady określone w prawie polskim"39.

$\mathrm{Na}$ obowiązek zachowania $\mathrm{w}$ tajemnicy oraz zabezpieczenia przed ujawnieniem lub niepożądanym wykorzystaniem wszystkiego, o czym adwokat dowiedział się w związku z wykonywaniem obowiązków zawodowych, zwraca uwagę cytowany już „Kodeks Etyki Adwokatów Kościelnych". Ta środowiskowa regulacja odnosi się do oczywistej w dzisiejszych czasach kwestii posługiwania się w pracy sądowej nowoczesnymi środkami elektronicznego utrwalania danych, zwracając uwagę, że w tym zakresie adwokat jest zobowiązany stosować oprogramowanie i inne środki zabezpieczające dane przed ich niepowołanym ujawnieniem. Przekazywanie informacji objętych tajemnicą zawodową, za pomocą środków społecznej komunikacji, wymaga od obrońcy zachowania szczególnej ostrożności i uprzedzenia klienta o ryzyku związanym z zachowaniem poufności przy wykorzystaniu tych środków. W kwestii ochrony danych, defensor powinien zastosować się zarówno do wymagań prawa kanonicznego, jak i świeckiego. Obowiązek związany z przestrzeganiem tajemnicy zawodowej adwokata kościelnego nie jest ograniczony w czasie ${ }^{40}$.

( $\$ 5$ „Dokumentacja spraw klienta”).W $\$ 7$ stanowi się: „1) Adwokat jest zobowiązany postępować $\mathrm{z}$ informacjami objętymi tajemnicą zawodową adwokata (dalej informacje poufne) w sposób uniemożliwiający zapoznanie się z nimi osobom trzecim; 2) Adwokat powinien przechowywać dokumenty i nośniki zawierające informacje poufne w miejscu i w sposób uniemożliwiający ich zniszczenie, zniekształcenie lub zaginięcie; 4) Adwokat powinien kontrolować dostęp pracowników kancelarii do informacji poufnych. Adwokat powinien dopuścić do informacji poufnych wyłącznie osoby zajmujące się prowadzeniem sprawy klienta, z którą związana jest informacja poufna” ( $\$ 7$ „Zasady dostępu do informacji objętych tajemnicą zawodową adwokata”).

39 Por. T. BiaŁobrzeski, Współpraca adwokatów z sądami kościelnymi, dz. cyt., s. 96.

40 Por. KEAK, art. 12. 
Oprócz obowiązków które posiada adwokat i praw, które mu przysługują, niezależnych od fazy, w jakiej znajduje się proces, obrońca posiada obowiązki i prawa, które związane są z poszczególnymi etapami przewodu.

Jeszcze przed wprowadzeniem sprawy, adwokat winien służyć klientowi, który się do niego zgłasza, doradztwem przedprocesowym. $\mathrm{Na}$ tym etapie winny dokonać się weryfikacja legitymacji procesowej (por. kan. 1674 n. $1 \mathrm{KPK})^{41}$ oraz rozeznanie, mające na celu ocenę istnienia ewentualnych przesłanek nieważności małżeństwa ( fumus iuris) i kwalifikację trybu procesowego. Jeśli istnieje szansa na pogodzenie małżonków, znajdujących się w kryzysie, który może być motywacją wszczęcia procesu, należy dążyć do ich pojednania, na drodze mediacji.

O znaczeniu przedprocesowego badania wypowiada się papież Franciszek w dokumencie reformującym proces małżeński. Ma ono na celu zapoznanie się z sytuacją małżonków oraz zebranie informacji użytecznych dla procesu sądowego. Choć, jak zauważa papież, dochodzenie to powinno mieć miejsce w ramach jednolitego diecezjalnego duszpasterstwa małżeństw, wydaje się użytecznym, by w procesie tym uczestniczyli także adwokaci kościelni ${ }^{42}$.

W tym kontekście należy zwrócić uwagę na to, że adwokatowi kościelnemu nie wolno udzielać pomocy prawnej, która ułatwiałaby popełnienie przestępstwa lub wskazywałaby możliwość uniknięcia odpowiedzialności a także naruszała doktrynę katolicką, zwłaszcza w kwestii nierozerwalności małżeństwa ${ }^{43}$.

Kolejny obowiązek powstaje w momencie oficjalnego przyjęcia sprawy przez adwokata i zgody na reprezentowanie strony w sądzie. Powoduje to konieczność dostarczenia do sądu zlecenia i potwierdzenia przyjęcia funkcji adwokata w procesie (por. kan. $1484 \$ 1 \mathrm{KPK}$ ).

\footnotetext{
41 Na tę kwestię zwracają uwagę autorzy Kodeksu Etycznego, zastrzegając, że adwokat kościelny nie może podjąć się prowadzenia sprawy, gdy zgłasza się z nią osoba nieupoważniona. Por. KEAK, art. 23.

42 Por. MIDI, Zasady proceduralne, art. 2.

43 Por. KEAK, art. 7.
} 
Jeśli adwokat nie został umieszczony na liście przy danym sądzie albo też nie jest mu on znany, powinien potwierdzić notarialnie autentyczność swojego podpisu na zleceniu. Możliwe jest także uwierzytelnienie podpisu u własnego proboszcza, albo też poprzez inny sąd, w którym adwokat już wcześniej występował ${ }^{44}$.

By zapobiec wygaśnięciu uprawnienia, przewodniczący trybunału może dopuścić pełnomocnika nawet bez okazania zlecenia, po złożeniu, w razie potrzeby, odpowiedniej gwarancji. Akt ten będzie jednak pozbawiony wszelkiej mocy, jeśli w terminie zawitym, określonym przez przewodniczącego, pełnomocnik nie przedstawi należycie zlecenia (por. kan. $1484 \$ 2$ KPK i art. $106 \$ 2$ DC). Przyjętego zlecenia adwokat nie powinien się zrzekać bez ważnej przyczyny (por. art. 110 n. 4 DC).

Jego stosunek z klientem jest oparty na zaufaniu. Dlatego też jeśli klient je utraci, etycznym zachowaniem obrońcy będzie wypowiedzenie pełnomocnictwa ${ }^{45}$. Powinien on także poinformować klienta o możliwości wypowiedzenia pełnomocnictwa, gdyby jego postępowanie powodowało dla adwokata konieczność udziału w grzechu ${ }^{46}$.

Doniosłe obowiązki adwokata wiążą się z przysięgami, które w sądzie spełniają ważną rolę w celu uwiarygodnienia występujących w nim uczestników procesu, a także zapewnienia ochrony tajemnicy podejmowanych czynności i akt procesowych. Adwokat może zatem zostać poproszony o złożenie przysięgi przez sędziego. W przypadku adwokatów występujących ad casum jest to obligatoryjne (por. 1455 $\S 3 \mathrm{KPK})$.

Również sam defensor powinien pouczyć klienta o ważności składanej przez niego przed zeznaniami przysięgi, a także zobowiązać swoich współpracowników (personel oraz wszelkie osoby zatrudnione przez niego podczas wykonywania działalności zawodowej) do

\footnotetext{
44 Por. R. Sztychmiler, Dynamiczna posługa adwokata..., dz. cyt., s. 98.

45 Por. KEAK, art. 26

46 Por. TAMżE, art. 21.
} 
złożenia przysięgi religijnej, mającej na celu zachowanie tajemnicy zawodowej ${ }^{47}$.

Istotnym obowiązkiem adwokata jest pomoc stronie w wyborze właściwego trybunału (por. kan. 1672 MIDI). To zobowiązanie winno być wykonywane z pełną uczciwością, mając na uwadze dobro wiernego, który stara się o stwierdzenie nieważności, ale także obiektywizm w osiągnieciu prawdy o jego małżeństwie. W wyniku reformy procesowej papieża Franciszka, poszerzyły się możliwości wyboru sądu właściwego do procedowania sprawy. Jest rzeczą etycznie niepożądaną, by adwokat stosując różne „wybiegi prawne”, starał się wnieść sprawę do sądu, który ma opinię „łagodniejszego” lub łatwiej orzekającego o nieważności małżeństwa, a który bez zastosowania owych „wybiegów” (np. fikcyjna zmiana zamieszkania stron lub świadków), tej właściwości rzeczywiście by nie posiadał. Tego rodzaju „fenomen” był wielokrotnie krytykowany przez Stolicę Apostolską ${ }^{48}$.

Adwokaci, którzy omijając prawo, starają się wydobywać sprawy z właściwych trybunałów, by korzystniej zostały rozstrzygnięte przed innymi, powinni być zawieszeni w wykonywaniu posługi, a nawet skreśleni z listy przez biskupa, stojącego na czele danego trybunału (por. kan. $1488 \$ 1 \mathrm{KPK}$ i art. 110 n. $4 \mathrm{DC})^{49}$.

Jeszcze przed sporządzeniem skargi pomoc adwokata będzie szczególnie użyteczna gdy chodzi o ustalenie rzeczywistych przyczyn nieważności (por. kan. 1057 KPK oraz kan. 1083-1117 KPK). Zdarza się, że w skardze do tytułu głównego zostają dołączone dodatkowe tytuły, z których częściej prowadzone są sprawy (np. kan. 1095 n. 3 KPK), które nie są poparte rzeczowymi argumentami i faktami. Działanie takie ma na celu zabezpieczenie się na wypadek nie orzeczenia nieważności w przypadku tytułu głównego, którego dowodzenie jest

\footnotetext{
47 Por. TAмże, art. 11, art. 21.

48 Por. A.G. Miziński, Status prawny adwokata $w$ Kościele łacińskim, dz. cyt., s. 382-383.

49 Por. W. GóRAlski, Rola adwokata w kościelnych procesach małżeńskich..., dz. cyt., s. 46 .
} 
trudne, tak aby uzyskać je z tytułu, który został dołączony niejako profilaktycznie.

Innym błędem jest zgłaszanie tytułów, które są ze sobą sprzeczne. Niekompatybilność taka zdarza się, mimo że skarga została sporządzona przez profesjonalnego pełnomocnika ${ }^{50}$. Jeśli zatem w sprawie od początku występuje adwokat, jego obowiązkiem jest pomoc stronie $\mathrm{w}$ takim zredagowaniu skargi, by zawierała ona wszystkie wymagane prawem elementy materialne i formalne.

Jedną z możliwych decyzji wikariusza sądowego, po zbadaniu formalności i zawartości merytorycznej skargi jest jej odrzucenie, kiedy okaże się, że posiada ona wady, które nie pozwalają przyjąć jej do przewodu sądowego. Taka decyzja winna być zakomunikowana stronie dekretem, wydanym quam primum (por. kan. $1505 \$ 1 \mathrm{KPK}$ ).

Przeciw decyzji o odrzuceniu skargi przysługuje stronie rekurs, do trybunału apelacyjnego, gdyż nie został jeszcze utworzony trybunał ad quo, który miał sprawę rozstrzygać. Przygotowanie pisma odpowiedniej treści i złożenie go w terminie zawitym 10 dni użytecznych, jest zadaniem, w którym stronie może pomóc profesjonalny pełnomocnik, jakim jest adwokat. Rekurs ten powinien zostać rozstrzygnięty jak najszybciej (expeditissime), a od niekorzystnego rozstrzygnięcia nie przysługuje środek odwoławczy, jakim jest apelacja (por. kan. $1504 \$ 4$ i kan. 1629 n. 5 KPK).

Wśród praw, jakie przysługują adwokatowi w czasie postępowania dowodowego, należy wyróżnić zgłaszanie, aktualizowanie i uzupełnianie dowodów w sprawie, jakimi mogą być nowi świadkowie, dokumenty, uzupełnienie zeznań, itp., a także prawo do zgłaszania przeciwdowodów, za pomocą wniosków procesowych czy też odwołań. Należy przy tym pamiętać, że prawnie zakazane jest

\footnotetext{
50 Na niektóre niekompatybilności tytułów zwrócił uwagę Remigiusz Sobański, wymieniając sprzeczność między: symulacją całkowitą i przymusem, symulacją całkowitą i częściową, symulacją i błędem prawnym, symulacją i warunkiem, symulacją i brakiem rozumu oraz brakiem rozeznania oceniającego. Por. R. SobAŃski, Orzekanie nieważności małżeństwa $z$ dwu (lub więcej) tytułów wadliwego konsensu, Ius Matrimoniale 11 (2000) nr 5, s. 139-150.
} 
przekazywanie przez adwokata sędziemu informacji, które pozostają poza aktami sprawy (kan. $1604 \$ 1 \mathrm{KPK}$ i art. $241 \mathrm{DC}$ ). Byłoby to nie tylko działaniem bezprawnym, ale również wysoce nieetycznym.

Adwokat ma prawo do obecności przy przesłuchaniach stron, świadków i biegłych (por. kan. 1559). Chociaż ustawodawca mówi jedynie o obecności, w doktrynie i praktyce sądowej chodzi rzecz jasna o obecność aktywną, a więc o zadawanie pytań, które odbywa się za pośrednictwem sędziego przesłuchującego ${ }^{51}$. Dla sprawności przesłuchania powinno dokonać się to poprzez załączenie pytań w formie pisemnej. Jest to także istotne ze względu na pomoc w zrozumieniu pytania, a także kontrolę poprawności jego zapisu w protokole. To ostatnie spełnia szczególnie ważną rolę, gdy przesłuchującym jest audytor, czy też sędzia delegowany, który nie zna całości sprawy, a jedynie jednorazowo wypełnia czynność procesową i nie musi posiadać wykształcenia kanonistycznego (kan. 1428 KPK).

Jednym $\mathrm{z}$ ważnych uprawnień dotyczących dostarczania dowodów jest uprawnienie strony, które może realizować z pomocą swojego adwokata, polegające na proponowaniu ekspertyzy biegłego, który jest specjalistą w dziedzinie, której ona dotyczy, albo też wskazanie jakie kompetencje powinien posiadać ekspert powołany przez sąd ${ }^{52}$.

Po zebraniu materiału dowodowego, stronie przysługuje prawo do zapoznania się z nim. Zadaniem adwokata na tym etapie, jest pouczenie strony o znaczeniu tego uprawnienia, a w kwestii jego realizacji, na jakie treści powinna ona zwrócić uwagę przy publikacji akt ${ }^{53}$.

Niezwykle ważnym zadaniem adwokata, które spoczywa na nim po zamknięciu postępowania dowodowego, jest napisanie w imieniu strony, w wyznaczonym przez sędziego terminie, odpowiedzi na uwagi obrońcy węzła małżeńskiego oraz głosu obrończego. Prawo to można zrealizować poprzez sporządzenie jednego lub dwu pism procesowych (por. kan. 1601 i kan. 1602 KPK).

\footnotetext{
51 Por. R. Sztychmiler, Dynamiczna posługa adwokata..., dz. cyt., s. 100.

52 TAMŻE, s. 101.

53 TAMŻE.
} 
Po wydaniu wyroku w sprawie, jeśli jest on w odczuciu strony dla niej niesprawiedliwy, adwokat powinien służyć pomocą w podjęciu decyzji o ewentualnej apelacji. Jeśli zaś strona się na to decyduje powinien ją sporządzić ${ }^{54}$.

Znaczenie tego środka odwoławczego jest szczególnie ważne po reformie papieża Franciszka, w której postanowił zrezygnować z wymogu dwu zgodnych wyroków, aby orzec nieważność małżeństwa. A zatem po upływie piętnastu dni, wyrok pierwszej instancji staje się wykonalny (kan. 1679). Adwokat powinien po dokonaniu oceny orzeczenia w ciągu piętnastu dni od zapoznania się z nim, jeśli uważa to za zasadne, zgłosić apelację do trybunału drugiej instancji, za pośrednictwem sądu orzekającego, a w ciągu kolejnych trzydziestu wysłać jej poparcie do sądu apelacyjnego (por. kan. 1630 i kan. 1633 KPK).

Sporządzenie apelacji nie należy do zadań łatwych. Nie może to być bowiem powtarzanie tez powodowych wnoszonych w skardze i w czasie zeznań, czy też udowadnianie racji jedynie poprzez przytaczanie treści, zaczerpniętych z akt sprawy. Apelacja powinna zawierać merytoryczne odniesienie do treści orzeczenia trybunału. Adwokat w świetle obowiązującego prawa i po dogłębnej analizie materiału dowodowego i orzeczenia winien wykazać, że brakuje podstaw do wydania zaskarżanego wyroku, ponieważ nie został on odpowiednio umotywowany lub dowody nie zostały przez sędziów ocenione prawidłowo, albo też jakiś argument przeciwny węzłowi zawarty w opinii biegłego nie został przez sędziów należycie rozważony ${ }^{55}$.

Profesjonalne oraz etyczne wypełnianie obowiązków adwokata i korzystanie z przysługujących mu uprawnień, przyczynia się wydatnie do osiągnięcia obiektywnej prawdy o małżeństwie, którego

\footnotetext{
54 G. P. Montini, Dopo la decisione gudiziale: apello e altre impugnazioni, w: REDAZIONe di QuAderni di DiRitto Ecclesiale (red.) La riforma dei processi matrimoniali di Papa Francesco. Una guida per tutti, Milano 2016, s. 107-117.

55 Por. G. Erlebach, Komentarz do kanonu 1687, w: G. Erlebach, A. Dzięga, J. Krukowski, R. Sztychmiler, Komentarz do Kodeksu Prawa Kanonicznego. Ksiegga VII. Procesy, t. V, s. 365-367.
} 
dotyczy proces, w którym reprezentuje on stronę lub obie z nich, jeśli tylko ich żądania nie są ze sobą sprzeczne (por. art. 102 DC).

\section{Kwestie związane $\mathrm{z}$ wynagrodzeniem adwokata}

Kwestie finansowe są delikatną materią, nie tylko w przypadku procesów kanonicznych. Gdy chodzi o adwokata kościelnego należy mieć na uwadze dwa aspekty tego zagadnienia. $Z$ jednej strony jest to jego praca, z której nierzadko musi utrzymać siebie i rodzinę, a $\mathrm{z}$ drugiej strony pełni on posługę w Kościele, w którym kwestie finansowe nie powinny być przeszkodą do korzystania $\mathrm{z}$ należnej wiernym ochrony swoich praw, w tym także prowadzenia procesów, również z udziałem wybranego obrońcy. Chociaż bowiem w przypadkach uzasadnionych jest możliwa bezpłatna porada prawna przez przydzielonego stronie przez sąd obrońcy, zatwierdzonego przy trybunale na stałe, to jednak strona powinna mieć swobodny dostęp do wybranego przez siebie w sposób wolny adwokata, a kwestie finansowe nie powinny stanowić $\mathrm{w}$ tym przeszkody ${ }^{56}$.

Nierzadko zdarza się jednak, że zapłata za sporządzenie skargi powodowej, której żąda obrońca, przekracza wysokość opłat sądowych całego procesu. Jedna sprawa to około dwa miesiące pracy adwokata (spotkania, analiza akt, pisanie pism i głosu obrończego), wynagrodzenie winno być zatem godziwe, ale także możliwe do przyjęcia przez stronę (między minimalnym a przeciętnym wynagrodzeniem w danym regionie). Powinno być także uzależnione od zarobków strony i mogłoby stanowić np. wysokość jednomiesięcznego jej wynagrodzenia z tytułu podejmowanej pracy. W polskich sądach kościelnych kwestia ta jest nadal nieuregulowana, co może sprzyjać

\footnotetext{
${ }^{56}$ Obowiązkiem adwokata figurującego na oficjalnej liście obrońców, jest występowanie na polecenie wikariusza sądowego w sprawach, w których trybunał przyznał stronie gratuitum patrocinium (por. art. $112 \$ 2$ DC). Tak wyznaczony do udziału w sprawie adwokat nie może uchylić się od podjęcia obrony bez przedstawienia przyczyny uznanej przez przewodniczącego (art. $307 \$ 2$ DC).
} 
nadużyciom w omawianej materii ${ }^{57}$. W polskiej kanonistyce, $\mathrm{w}$ powyższych kwestiach istnieją dwa rozbieżne stanowiska. Przedstawicielem jednego z nich jest Ryszard Sztychmiler, który uważa, że adwokaci sami powinni „regulować poziom wynagrodzenia odpowiednio do zamożności zainteresowanych oraz swoich możliwości czasowych" ${ }^{58}$.

Odmienne stanowisko reprezentuje Artur Grzegorz Miziński, którego zdaniem „pewne wytyczne, a nawet granice najwyższego i najniższego wynagrodzenia adwokata powinien ustanowić biskup moderator trybunału"59.

Przy rozważaniach o sprawach związanych z wynagrodzeniem za pracę, warto przywołać przepis instrukcji procesowej Dignitas Connubii, odnośny do należnej zapłaty jakiemukolwiek pracownikowi trybunału. Art. 308 instrukcji, poleca biskupowi diecezjalnemu troskę o to, by z powodu sposobu postępowania tychże pracowników, a także z powodu zbyt wygórowanych opłat sądowych wierni nie byli powstrzymywani od skorzystania z posługi sądowej z wielką szkodą duchową, wszak dobro dusz winno być najwyższym prawem w Kościele ${ }^{60}$.

Jeszcze dalej idą postulaty III Nadzwyczajnego Zgromadzenia Ogólnego Synodu Biskupów z roku 2014, którego Relatio papież Franciszek nakazał opublikować. Wielu ojców synodalnych domagało się, by na ile to możliwe, zapewniono w sądach kościelnych bezpłatne

\footnotetext{
57 Podejmując próbę regulacji kwestii finansowych, można posłużyć się chociażby doświadczeniem włoskim. Tamtejsze sądy regionalne posiadają wyliczenia, szczegółowo wyceniające czynności pracowników sądów oraz uczestników procesu, w tym adwokatów. Przykłady takich taryfikatorów (stan na rok 2007 i 2010), zamieszcza w swojej monografii A. Miziński. Por. A.G. Mizıński, Status prawny adwokata w Kościele łacińskim, dz. cyt., s. 591-597.

58 R. SzTychmiler, Adwokat w procesie o nieważność matżeństwa, w: T. Rozkrut (red.), Proces matżeński w świetle Dignitas connubii - pierwsze doświadczenia. Materiały z ogólnopolskiego spotkania pracowników sądownictwa kościelnego w Gródku nad Dunajcem w dniach 11-12 czerwca 2007 roku, Tarnów 2008, s. 115.

59 A. G. Mizıński, Status prawny adwokata w Kościele łacińskim, dz. cyt., s. 271.

60 Por. W. Góralski, Rola adwokata $w$ kościelnych procesach małżenskich w świetle KPK z 1983 roku oraz instrukcji „Dignitas connubii”, Prawo Kanoniczne 49 (2006) nr 3-4, s. 45.
} 
procesy de nullitate ${ }^{61}$. Postulat ten znalazł się ostatecznie w motu proprio papieża Franciszka Mitis Iudex Dominus Iesus, w założeniach do reformy procesowej z 2015 roku, w których papież wskazuje na Konferencje Biskupów, jako na te, które „(...) winny, z zachowaniem sprawiedliwego i godnego wynagrodzenia pracowników sądów, w miarę możliwości zadbać, aby proces był bezpłatny" ${ }^{\prime 2}$.

Jak słusznie zauważa Adam Bartczak, samą ideę należy uznać za słuszną, lecz jej realizacja nie należy do rzeczy prostych, gdyż pogodzenie utrzymania wykwalifikowanej kadry sądowniczej, przy jednoczesnym braku opłat za proces jest zadaniem praktycznie niewykonalnym, zwłaszcza że nawet obecnie, gdy strony uiszczają opłaty sądowe, wynagrodzenia pracowników sądów są niskie ${ }^{63}$.

Oczywiście powyższe postulaty nie do końca odnoszą się wprost do adwokatów, gdyż ich wynagrodzenie pokrywają strony. Jednak pozostaje pytanie, jak odnieść się do sytuacji, w której strony niekiedy dziwiąc się opłatom w sądach kościelnych, proszą o zwolnienie $\mathrm{z}$ nich, a równocześnie są $\mathrm{w}$ stanie pokrywać honoraria wybranych przez siebie adwokatów?

Zarówno w Kodeksie Prawa Kanonicznego, jak i w instrukcji Dignitas Connubii zawarto zakaz, dotyczący układania się adwokata ze stroną (lub stronami) o wygórowane wynagrodzenie. Gdyby układ taki miał miejsce, jest on w świetle obowiązujących przepisów nieważny (por. kan. $1488 \$ 1$ KPK i art. 110 n. 2 DC). Adwokat sprzeniewierza się także urzędowi przez przyjmowanie podarunków lub składanych obietnic (por. kan. 1489 KPK i art. 110 n. 3 DC) ${ }^{64}$.

Sprawom finansowym poświęca uwagę także Kodeks Etyki Adwokata Kościelnego, w którym postanowiono, że w tych kwestiach

${ }^{61}$ Relatio synodi. Wyzwania duszpasterskie związane z rodzina w kontekście ewangelizacji, L'Osservatore Romano (wyd. polskie) 11 (366) 2014, art. 48 [s. 8-18].

62 MIDI, pkt. VI.

63 Por. A. BARtczak, Podstawowe założenia reformy kanonicznego procesu małżeńskiego $w$ motu proprio Franciszka „Mitis Iudex Dominus Iesus”, Łódzkie Studia Teologiczne 25 (2016) nr 2, s. 66 [57-70].

${ }^{64}$ Por. W. Góralski, Rola adwokata $w$ kościelnych procesach małżeńskich..., dz. cyt., s. 46. 
„(...) obowiązuje adwokata kościelnego w stosunku do klienta szczególna skrupulatność. Adwokat kościelny ma obowiązek poinformować klienta o wysokości honorarium lub o sposobie jego wyliczenia, w tym wysokości podatków" ${ }^{65}$.

W świetle tego dokumentu, adwokat ma ponadto obowiązek dążyć do rozstrzygnięć pozwalających zaoszczędzić klientowi kosztów oraz doradzać ugodowe zakończenie sprawy, gdy jest to możliwe ${ }^{66}$.

\section{Współpraca adwokata $\mathrm{z}$ trybunałem kościelnym}

Wszystkich uczestniczących w procesie powinien charakteryzować duch współpracy.

Udział adwokata w sprawie o orzeczenie nieważności małżeństwa stanowi równowagę dla obrońcy węzła małżeńskiego. Stają oni na odmiennych pozycjach wyjściowych: obrońca węzła - pro vinculo, adwokat - pro nullitate, ale obaj muszą zostać wierni zasadzie salva semper veritate ${ }^{67}$.

Nie powinno zatem istnieć między nimi współzawodnictwo zmierzające do osiągnięcia własnego celu, jakim jest „wygranie sprawy”, a działaniami powinna kierować chęć współpracy z sędzią, który ma orzekać, opierając się na pewności moralnej, osiągając ją po rozważeniu faktów i zastosowaniu wiedzy oraz osądu sumienia. Naświetlenie sprawy z różnych pozycji procesowych niesie ze sobą wydatną pomoc w zrealizowaniu tego zadania.

Chociaż motywem działania adwokata jest „prawda strony”, to nade wszystko pozostaje on w służbie obiektywnej prawdy materialnej ${ }^{68}$.

Omawiając wyżej obowiązki i uprawnienia adwokata, wskazano jednocześnie na pola jego współpracy z trybunałem. W tym miejscu należy jeszcze wskazać na sposób korespondowania z sądem, co

\footnotetext{
65 KEAK, art. 18.

66 Por. TAMŻE, art. 19.

67 A. G. Mizıński, Adwokat - „cooperator veritatis” w procesie o orzeczenie nieważności mał̇̇ństwa, Prawo Kanoniczne 59 (2016) nr 1, s. 88.

68 TAMŻE, s. 89.
} 
stanowi zwyczajne działanie w procedurze związanej z prowadzeniem procesu.

W kan. $1509 \$ 1$ KPK oraz art. $130 \$ 1$ DC prawodawca wskazuje sposób przekazywania korespondencji związanej ze sprawą do osób zainteresowanych. Powinno się ono dokonywać „przez pocztę lub w inny sposób, który jest najpewniejszy".

W Polsce nie ma norm partykularnych w tej materii. Stąd sędzia ma prawo rozstrzygnąć, w jaki sposób należy doręczyć pismo sądowe. Najlepiej jest to uczynić listem poleconym z potwierdzeniem odbioru. Można się również posłużyć posłańcem, który odbierze od adresata pokwitowanie odbioru ${ }^{69}$.

Jak zauważa T. Białobrzeski, w praktyce korespondencja do stron przekazywana jest za pośrednictwem poczty, listami poleconymi. W przypadku adwokatów powstaje jednak problem związany z ilością korespondencji. Zdarzają się sytuacje, że danego dnia do tego samego adwokata jest kierowanych kilka pism $\mathrm{z}$ różnych spraw. $\mathrm{W}$ tej sytuacji wysyłanie ich pocztą w listach poleconych staje się uciążliwe i kosztowne. Dobrym rozwiązaniem wydaje się wysyłanie korespondencji jednorazowo z kilku dni lub odbiór pism przez adwokata w siedzibie sądu. Zdarzają się też sytuacje, że na daną godzinę są wezwane strony lub świadkowie $\mathrm{z}$ dwóch różnych spraw, w których występuje ten sam adwokat. Aby nie dochodziło do takich sytuacji, konieczne jest porozumienie między sędziami prowadzącymi poszczególne sprawy, w których występuje dany adwokat kościelny. Z drugiej strony jest to też dodatkowe utrudnienie w pracy trybunału, ponieważ w terminarzu wezwań trzeba uwzględnić, oprócz obecności sędziego przewodniczącego, sędziego audytora, obrońcy węzła małżeńskiego i notariusza, także obecność adwokata ${ }^{70}$.

69 Por. H. Stawniak, Komentarz do art. 130 Dignitas connubii, w: T. Rozkrut (red.), Komentarz do Instrukcji procesowej „Dignitas connubii”, Sandomierz 2007, s. 200-201; por. S. Panizo Orallo, Comentario al can. 1509 CIC, w: Á. Marzoa, J. Miras, R. Rodríguez-Ocaña (red.), Comentario exegético al Código de Derecho Canónico, t. IV/2, Pamplona 2002, s. 1222-1223.

70 Por. T. BiaŁobrzeski, Współpraca adwokatów z sądami kościelnymi, dz. cyt., s. 97 
Wszelkie podejmowane działania we współpracy z sądem, powinny być wykonywane przez adwokata nie tylko lege artis, ale także z poszanowaniem konwencji, zwyczajów, szacunku i kanonów kultury osobistej. Etyka zawodu domaga się aby czynności prawne adwokata kościelnego tak na gruncie prywatnym jak i służbowym dawały gwarancje jego uczciwości, rzetelności oraz pełnej łączności z Kościołem katolickim i jego nauką ${ }^{71}$. Jest on zobowiązany do obrony interesów swego klienta w sposób odważny i honorowy, ale nie może to oznaczać braku szacunku dla trybunału oraz braku kultury osobistej. Zasady te obowiązują, rzecz jasna przy zachowaniu naczelnej zasady prawdy obiektywnej w procesie kościelnym, co jasno wyraża zasada ogólna polskiego kodeksu etycznego ${ }^{72}$.

Ten sam dokument korpusu adwokatów kościelnych, poświęca relacjom adwokatów $\mathrm{z}$ trybunałem cały rozdział trzeci.

Zwraca się w nim uwagę na życzliwość, takt i umiar w kontaktach adwokata $\mathrm{z}$ sądem oraz wobec urzędów i instytucji, przed którymi występuje. Adwokaci kościelni mają prawo oczekiwać w tej kwestii na wzajemność ${ }^{73}$.

Nieetycznym jest publiczne demonstrowanie swojego osobistego stosunku do klienta, osób bliskich klientowi oraz innych osób uczestniczących w postępowaniu, podobnie jak niedopuszczalne jest okazywanie przez adwokata zażyłości z pracownikami sądu czy innych instytucji diecezjalnych. W żaden sposób zachowanie adwokata nie może rodzić u uczestników postępowania przeświadczenia, że ze względu na jego bliskie relacje z wyżej wymienionymi, strona przez niego reprezentowana mogłaby być traktowana w sposób uprzywilejowany ${ }^{74}$.

Obrońca prawidłowo zawiadomiony przez sąd o czynnościach procesowych zobowiązany jest brać w nich udział, a jeśli nie jest to możliwe, ma obowiązek zawiadomić trybunał, przed którym występuje,

\footnotetext{
71 Por. KEAK, art. 27.

72 Por. TAMżE, art. 18.

73 Por. TAMŻE, art. 13.

74 Por. TAмżE, art. 14-15.
} 
o niemożności wzięcia udziału w zaplanowanych czynnościach oraz usprawiedliwiać swoje niestawiennictwo. Niedopuszczalne jest, by niestawiennictwo adwokata było działaniem umyślnym mającym na celu przewlekłość postępowania ${ }^{75}$.

Gdyby obrońca utracił pełnomocnictwo, ma obowiązek bezzwłocznie zawiadomić o tym fakcie trybunał kościelny, natomiast adwokat znajdujący się na liście stałych obrońców ma obowiązek prowadzenia sprawy do momentu zwolnienia go przez właściwego sędziego ${ }^{76}$.

Za naruszenia, których może dopuścić się adwokat przewidziane są odpowiednie kary.

Na skutek poważnej przyczyny adwokat, może zostać usunięty przez przewodniczącego umotywowanym dekretem, wydanym z urzędu albo na żądanie strony (por. kan. 1487, art. 109 DC).

Ci którzy dopuścili się przestępstwa przeciwko powierzonemu im zadaniu, powinni być ukarani zgodnie z przepisami prawa (por. kan. 1386; kan. 1389; kan. 1391 n. 2; kan. $1470 \$ 2$; kan. 1488-1489 KPK; art. $111 \$ 1 \mathrm{DC})$. Przewidziane przez przywołane kanony prawa kanonicznego kary to: upomnienie, grzywna, zawieszenie, skreślenie z listy. Kary te można stosować za różnego rodzaju wykroczenia. Jednym $\mathrm{z}$ nich jest przyjmowanie darów lub składanie przyrzeczeń. W takim przypadku kara jest obligatoryjna nieoznaczona (por. kan. 1386 KPK). Innym przestępstwem będzie nadużycie władzy lub zadania. Tu także kara jest obligatoryjna, wymierzona stosownie do wielkości czynu lub zaniedbania, nie wyłączając pozbawienia urzędu (por. kan. $1389 \$ 1$ ). Zawinione, bezprawne podjęcie lub pominięcie z czyjąś szkodą aktów posługi albo zadania, zagrożone jest karą obligatoryjną nieoznaczoną (kan. $1389 \$ 2$ KPK). Posługiwanie się fałszywym lub zmienionym dokumentem w sprawie kościelnej obwarowane jest natomiast karą fakultatywną nieoznaczoną (por. kan. 1391 n. 2 KPK).

Do funkcji adwokata odnoszą się także zapisy art. 75 procesowej instrukcji Dignitas connubii, w której postanowiono, że jeśli pomocnicy sądu, a do takich należy zaliczyć defensorów, nie stają

75 Por. TAMżE, art. 16.

76 Por. TAMżE, art. 17. 
na wysokości zadania z powodu nieudolności, utraty dobrego imienia, niedbalstwa albo nadużycia, mogą przez biskupa moderatora albo przez zebranie biskupów, zostać ukarani poprzez zastosowanie odpowiednich środków, nie wykluczając, jeśli będzie to konieczne, zakazu wykonywania funkcji patrona w swoim sądzie (por. art. 75 $\$ 2$ DC). Ten sam artykuł przypomina, że w myśl kan. $128 \mathrm{KPK}$, kto jakąkolwiek czynnością dokonaną nielegalnie z winy umyślnej lub nieumyślnej wyrządził komuś krzywdę, obowiązany jest do naprawienia wyrządzonej szkody (por. art. $75 \$ 3$ DC).

Jak konstatuje Wojciech Góralski, przypominając normę kan. $1470 \$ 2$ KPK, uchybienia adwokata, szczególnie w zakresie szacunku i posłuszeństwa trybunałowi, czy też zachowania tajemnicy, uprawniają sędziego do zawieszenia go w wykonywaniu swojej funkcji w trybunałach kościelnych. Gdyby adwokat nie wypełniał swojego zadania $z$ należytą starannością, winien zatem zostać upomniany przez przewodniczącego z urzędu lub na wniosek strony albo też obrońcy węzła małżeńskiego oraz, jeśli uczestniczy w sprawie, rzecznika sprawiedliwości (art. $307 \$ 3$ DC) ${ }^{77}$.

Naruszeniem godności zawodu adwokata kościelnego są nie tylko przykłady postępowania, które zostały powyżej opisane na podstawie norm prawa kanonicznego, ale także działania, które wynikają z zasad etycznych, a które mogłoby poniżyć w opinii publicznej lub poderwać zaufanie stron i innych osób do Kościoła katolickiego ${ }^{78}$.

Obowiązkiem adwokata kościelnego jest zatem przestrzeganie nie tylko norm prawa kanonicznego, zgodnie z hierarchią źródeł prawa, ale i etyki katolickiej, a także wspieranie dobrego imienia Kościoła katolickiego oraz godności zawodu adwokata kościelnego ${ }^{79}$.

Ewentualnych naruszeń zasad etyki katolickiej i godności zawodu, adwokat nie może usprawiedliwiać, powołując się na sugestie klienta. Nie wolno więc świadomie podawać trybunałowi nieprawdziwych

\footnotetext{
77 Por. W. GóRALsKi, Rola adwokata $w$ kościelnych procesach małżeńskich..., dz. cyt., s. 44.

78 Por. KEAK, art. 3.

79 Por. TAMżE, art. 4.
} 
informacji ani przedkładać dowodów niegodziwych, lub w taki sposób zdobytych ${ }^{80}$.

Jest rzeczą bezsporną, że adwokat, reprezentując stronę w danej sprawie jest niezdolny do występowania w niej w charakterze świadka (por. kan. $1550 \$ 2$ n. $1 \mathrm{KPK}$ ).

Obrońca nie może także się uchylić od odpowiedzialności za formę i treść pism procesowych przez niego zredagowanych, nawet jeśli zostałyby podpisane przez jego współpracowników. Sporządzając ich treść, wypowiedzi i argumenty powinien formułować w taki sposób, aby broniąc interesów klienta, uczciwie nawiązywały one do meritum sprawy. Obrońca nie ponosi natomiast odpowiedzialności za zgodność z prawdą faktów podanych mu przez klienta ${ }^{81}$.

O ile powyższa sytuacja nie jest przez niego zawiniona, o tyle nieuczciwym wobec strony, ale także wobec sądu byłoby wnoszenie sprawy w przypadku braku faktów na poparcie tezy powodowej, właściwych do orzeczenia nieważności małżeństwa lub w przypadku niemożliwości ich udowodnienia. Taka postawa, oprócz niezgodności ze sztuką, rodziłaby u strony nieuzasadnione nadzieje na pozytywny wyrok. Nierzadko takie zachowanie obrońcy skutkuje wzrostem ilości prowadzonych spraw w sądach oraz wyższym odsetkiem wyroków negatywnych ${ }^{82}$.

Zarówno zachowania, które wymuszają na adwokacie kościelnym prawo, jak i zasady etyki zawodowej, mają na celu uczynienie uczciwym i transparentnym postępowanie sądowe, usprawnienie procedowania, ale i uczynienie sprzyjającymi współpracy, wzajemne kontakty adwokata i sądu. Wszystkim uczestnikom procesu winna bowiem przyświecać idea dotarcia do obiektywnej prawdy o małżeństwie, którego dotyczy ów proces, w którym biorą oni udział.

\footnotetext{
80 Por. TAMżE, art. 5-6.

81 Por. TAMżE, art. 8-9, art.20.

82 Por. T. BiaŁobrzeski, Współpraca adwokatów z sqadami kościelnymi, dz. cyt., s. 88 .
} 


\section{Zakończenie}

Instytucja adwokata kościelnego istnieje od wieków. W obowiązującym Kodeksie Prawa Kanonicznego z 1983 r. na jej określenie, oprócz łacińskiego terminu advocatus, zostały użyte także dwa inne terminy: patronus i defensor. Określenie patronus, czyli obrońca, występuje w kan. 1490, 1678, 1701 § 2 i 1738. W kan. $1481 \S 3$ w tekście oryginalnym użyto terminu defensor.

Udział adwokata $\mathrm{w}$ kanonicznym procesie o stwierdzenie nieważności, ma być pomocą dla strony w skutecznym korzystaniu ze środków ochrony swoich praw i dochodzeniu do wyegzekwowania swoich żądań. Szczególnego znaczenia pomoc profesjonalnego pełnomocnika nabrała po roku 2015, w którym papież Franciszek dokonał reformy przepisów proceduralnych procesu de nullitate.

Rezygnacja $\mathrm{z}$ dwuinstancyjności, powoduje, że wyrok wydany w pierwszej instancji po upływie ustawowych terminów może stać się wykonalny. Ważne jest więc, aby proces został poprowadzony ze szczególną starannością, o którą winna zabiegać także każda z jego stron, w czym wydatnie może pomóc jej obrońca. W przypadku niesprawiedliwego, w odczuciu strony wyroku, defensor może skutecznie pomóc w skorzystaniu ze środka odwoławczego w postaci apelacji.

Wszystkie działania adwokata, dokonywane na różnych etapach procesu, muszą być zgodne z normami prawa kanoniczego, ale także z zasadami etyki katolickiej oraz normami deontologicznymi, które formułują zarówno normy prawa pozytywnego, prawo moralne, jak i regulacje środowiskowe w postaci kodeksów etycznych.

Coraz powszechniejszy udział w procesach adwokatów ujawnia potrzebę regulacji kwestii, które do tej pory nie są nimi objęte. Są to zatem postulaty de lege ferenda. Wśród zagadnień domagających się zajęcia stanowiska ustawodawcy znajdują się: sposób weryfikacji przymiotu nienaruszonej sławy adwokata, co może uczynić uszczegóławiając ogólny przepis kan. 1483 KPK ustawodawca partykularny; prawny wymóg stałego dokształcania się obrońców, na wzór adwokatów cywilnych; sposoby przechowywania dokumentów procesowych i prowadzenia korespondencji z trybunałem oraz kwestie finansowe, 
związane $\mathrm{z}$ pracą adwokata. $\mathrm{W}$ tych ważnych materiach brak jest szczegółowych przepisów, co może powodować trudności, błędy, a niekiedy nawet nadużycia ze strony adwokatów kościelnych.

Niektóre z naruszeń zagrożone są karami, przewidzianymi przez prawo, jednak w polskim Kodeksie Etyki Adwokata Kościelnego, który jest regulacją środowiskową, pomimo wyliczenia niektórych niepożądanych działań obrońcy, brakuje związanych z nimi zasad odpowiedzialności dyscyplinarnej. Ich ustanowienie z pewnością pomogłoby w weryfikacji osób działających na rynku prawnym, oferujących także usługi z zakresu prawa kanonicznego.

Dla uczciwości i należytej ekonomii procesowej, wszyscy zaangażowani przy danej sprawie, choć ich pozycje procesowe są różne, w celu osiągnięcia obiektywnej prawdy o małżeństwie, które jest przedmiotem procesu, winni pracować pro rei veritate, przestrzegając prawa, chrześcijańskiej doktryny moralnej, etyki zawodowej, profesjonalizmu oraz poszanowania zasad współżycia międzyludzkiego, wśród których szacunek dla każdego zajmuje miejsce naczelne.

\section{Advocate deontology in the process of the nullity of marriage}

\section{Summary}

The article presents the duties and rights of an advocate who applies in a process of the nullity of marriage, conducted by a church court. Not only are the duties and rights of a defender provided for by canon law discussed, but also the manner of their implementation, taking into account ethical standards, which are an important source of due behavior, and in the case of a church lawyer, constitute his code of ethics.

A separate place was dedicated to financial issues related to the work of an advocate and the rules that should apply to mutual relations of process participants, especially in the cooperation between the advocate and the church court. 